\title{
Supporting Information for Degradation of Disinfection Byproducts by Carbonate Green Rust
}

\author{
Chan Lan Chun, Raymond M. Hozalski, and William A. Arnold \\ Department of Civil Engineering, University of Minnesota, 500 Pillsbury Dr. SE, Minneapolis, \\ Minnesota 55455-0116

\section{Environmental Science and Technology}

December 14, 2006

Section S1. Chemical purity and supplier information

Page

Section S2. Synthesis and characterization of $\mathrm{GR}\left(\mathrm{CO}_{3}{ }^{2-}\right)$

Section S3. GR( $\left(\mathrm{CO}_{3}{ }^{2-}\right)$ aging

Section S4. Reactor setup and sampling

S2

Section S5. Analytical Methods

S2

Section S6. Kinetic modeling

S3

Section S7. Determination of $\mathrm{E}_{1}{ }^{\mathrm{H}}$ values for TBAA and DBAA

S4

S5

Figure S1. Degradation of TCAA and TBAA by GR( $\left(\mathrm{CO}_{3}{ }^{2-}\right)$

Figure S2. Degradation of BAA by $\mathrm{GR}\left(\mathrm{CO}_{3}{ }^{2-}\right) \quad$ S6

Figure S3. Degradation of TCAN and DCAN by GR( $\left(\mathrm{CO}_{3}{ }^{2-}\right)$ in the presence of $\quad$ S7 MOPS buffer and carbonate buffer

Figure S4. Degradation of 1,1,1-TCP and TCAh by GR( $\left(\mathrm{CO}_{3}{ }^{2-}\right) \quad$ S8

Figure S5. Dissolved oxygen in $\mathrm{GR}\left(\mathrm{CO}_{3}{ }^{2-}\right)$-free control experiment-DO meter $\quad$ S9

Figure S6. Dissolved oxygen in $\mathrm{GR}\left(\mathrm{CO}_{3}{ }^{2-}\right)$-free control experiment- DO CHEMets ${ }^{2}$. S9

Figure S7. Sorption isotherm of Fe(II) onto magnetite $\quad$ S10

Figure S8 Settling of GR( $\left(\mathrm{CO}_{3}{ }^{2-}\right)$ in MOPS buffer and carbonate buffer $\quad$ S11

Figure S9. Aqueous $\mathrm{Fe}(\mathrm{II})$ in $\mathrm{GR}\left(\mathrm{CO}_{3}{ }^{2-}\right)$-free control experiment $\quad \mathrm{S} 12$

Figure S10. Correlation between reduction rate and one-electron reduction potential $\quad$ S13

References 
Section S1. Chemical purity and supplier information

The following chemicals were purchased from Sigma Aldrich and used as received: trichloronitromethane (TCNM; 99.6\%), trichloroacetonitrile (TCAN; 98\%), dichlroacetonitrile (DCAN; 98\%), trichloroacetamide (TCAM; 99\%), 1,1,1-trichloropropanone (1,1,1-TCP; Library product), 1,1-dichloropropanone (1,1-DCP; 98\%), trichloromethane (TCM; 99.9\%), trichloroacetaldehyde hydrate (TCAh, 99 \%), trichloroacetic acid (TCAA, 99\%), dichloroacetic acid (DCAA; 99\%), chloroacetic acid (CAA, 99\%), tribromoacetic acid (TBAA, 99\%), dibromoacetic acid (DBAA, 99\%), bromoacetic acid (BAA, 99\%), nitromethane (NM; 99.34\%), and methylamine (MA, 39.9\% weight in water). Dichloronitromethane (DCNM; 95.13\%) and chloronitromethane (CNM; 92.89\%) were obtained from CanSyn Chemical Corporation and dichloroacetaldehyde hydrate (DCAh) (96\%) was purchased from TCI America. Reagent grade methanol, acetone and methyl tertiary butyl ether (MTBE) were obtained from Fisher. A 3morpholinopropanesulfonic acid (MOPS; 99.5\%, Sigma) buffer $\left(\mathrm{pK}_{\mathrm{a}}=7.2\right.$ at $\left.20{ }^{\circ} \mathrm{C}, 25 \mathrm{mM}\right)$ was adjusted to $\mathrm{pH} 7.5$ with $5 \mathrm{M} \mathrm{NaOH}$ (97\%, Aldrich) and then was deoxygenated by argon sparging. Carbonate buffer $\left(\mathrm{pK}_{\mathrm{a}}=7.1\right.$ at $\left.0{ }^{\circ} \mathrm{C}, 50 \mathrm{mM}\right)$ was prepared by dissolving sodium bicarbonate (99.7 \%, Fisher) in deoxygenated Milli-Q water and was then adjusted to $\mathrm{pH} 7.5$ with $2 \mathrm{M} \mathrm{H}_{2} \mathrm{SO}_{4}$. Ultra-high purity argon was obtained from TriState Airgas, and was purified using an in-line molecular sieve and oxygen traps. For capillary electrophoresis analysis, sodium phosphate dibasic (98+\%, EM Science), sodium phosphate monobasic (99.4\%, Fisher), hexadimethrine bromide (100\%, Aldrich), sodium acetate trihydrate (100\%, Fisher), sodium bromide (100\%, Fisher), sodium chloride (100\%, Mallinckrodt Baker Inc.), and tetradecyltrimethylammonium bromide (99\%, Sigma) were used. $\mathrm{FeCl}_{2}$ (98\%, Aldrich), $\mathrm{FeCl}_{3} \cdot 6 \mathrm{H}_{2} \mathrm{O}$ (99\%, Fisher), and sodium carbonate (99.5\%, Sigma) were used to synthesize (GR( $\left.\mathrm{CO}_{3}{ }^{2-}\right)$. FerroZine (97\%, Aldrich), hydroxylamine hydrochloride (99\%, Aldrich), ammonium hydroxide (29.7\% solution, Mallinckrodt), hydrochloric acid (37.4\%, Mallinckrodt), and ammonium acetate (98\%, Mallinckrodt) were used for quantification of ferrous iron. All aqueous solutions were prepared with Milli-Q water (Millipore).

Section S2. Synthesis and characterization of $\mathrm{GR}\left(\mathrm{CO}_{3}{ }^{2-}\right)$

Synthesis of $\mathrm{GR}\left(\mathrm{CO}_{3}{ }^{2-}\right)$ was performed in an anaerobic chamber $\left(97 \% \mathrm{~N}_{2} / 3 \% \mathrm{H}_{2}\right.$, Coy Laboratory Products) using deoxygenated Milli-Q water at $22 \pm 3{ }^{\circ} \mathrm{C}$. $\mathrm{GR}\left(\mathrm{CO}_{3}{ }^{2-}\right)$ was prepared using a modification of the method of Williams and Scherer (1). Solutions of $125 \mathrm{mM} \mathrm{FeCl}_{2}$ and $25 \mathrm{mM} \mathrm{FeCl}_{3} \cdot 6 \mathrm{H}_{2} \mathrm{O}$ (250 mL each) were separately prepared and were then adjusted to $\mathrm{pH} 7$ using $1 \mathrm{M} \mathrm{Na}_{2} \mathrm{CO}_{3}$. The $\mathrm{FeCl}_{3}$ solution was added drop-wise to the magnetically stirred $\mathrm{FeCl}_{2}$ solution. The mixed $\mathrm{Fe}(\mathrm{II}) / \mathrm{Fe}(\mathrm{III})$ solution was maintained at $\mathrm{pH} 8.0$ using $1 \mathrm{M} \mathrm{Na}_{2} \mathrm{CO}_{3}$ under vigorous mixing until the $\mathrm{pH}$ of the solution no longer changed (approximately $2 \mathrm{~h}$ ). The resulting bluish-green precipitates were separated from the suspension using a high-performance centrifuge (J2-HS, Beckman). The g-value for centrifugation was 4940. The precipitates were washed with deoxygenated acetone and then were dried under argon gas in a hood at $22 \pm 3{ }^{\circ} \mathrm{C}$. After returning the dried solid to the anaerobic chamber, the solid was ground into fine powder using a mortar and pestle and passed through a 100-mesh sieve. Particles passing through the sieve were used for the $\mathrm{GR}\left(\mathrm{CO}_{3}{ }^{2-}\right)$ aging and DBP reaction experiments. X-ray diffraction

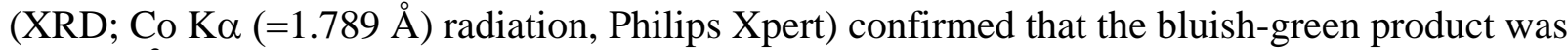
$\mathrm{GR}\left(\mathrm{CO}_{3}{ }^{2-}\right)$ and no other iron oxides were detected. Samples ( 30 mg) were mixed with glycerol 
to minimize oxidation during handling and analysis via XRD. Continuous scans from 5 to $80^{\circ} 2 \theta$ were collected at a scan rate of $2.4^{\circ} 2 \theta / \mathrm{min}$.

Section S3. $\mathrm{GR}\left(\mathrm{CO}_{3}{ }^{2-}\right)$ aging

The stability of $\mathrm{GR}\left(\mathrm{CO}_{3}{ }^{2-}\right)$ was evaluated with and without a DBP (TCAN) present in batch experiments. Mineralogical changes were monitored with XRD analysis. Two batch reactors were prepared to be sacrificed at each aging time (1, 3, 5, 10, 24, and $48 \mathrm{~h})$. Batch reactors contained a $2.4 \mathrm{~g} / \mathrm{L} \mathrm{GR}\left(\mathrm{CO}_{3}{ }^{2-}\right)$ suspension buffered at $\mathrm{pH} 7.5$ with deoxygenated $25 \mathrm{mM}$ MOPS buffer or $50 \mathrm{mM}$ carbonate buffer. Each headspace-free reactor was capped with a PTFElined septa and an aluminum crimp cap. The assembly of reactors was conducted in an anaerobic chamber. After preparation, the reactors were removed from the chamber and reactors were mixed around their longitudinal axes on a rotator (Glas-Col) at a speed of $50 \mathrm{rpm}$ at $22 \pm 3{ }^{\circ} \mathrm{C}$. After the desired aging time, one reactor was spiked with TCAN, and the other bottle was centrifuged to collect the solid for XRD analysis. The DBP reaction experiment was performed using the methods described below. Prior to initiating the experiment with TCAN, a sample was taken to measure the aqueous Fe(II) concentration in the reactor. The aqueous Fe (II) was measured using a modified Ferrozine method (2) after filtration through a $0.2 \mu \mathrm{m}$ PTFE Gelman Acrodisk syringe tip filter. For XRD analysis, solid collection and sample preparation were conducted in the same manner as for the freshly synthesized $\mathrm{GR}\left(\mathrm{CO}_{3}{ }^{2-}\right)$.

Section S4. Reactor setup and sampling

$\mathrm{GR}\left(\mathrm{CO}_{3}{ }^{2-}\right)$ was freshly prepared for each set of experiments. Batch experiments were carried out in $123 \mathrm{~mL}$ serum bottles containing a $2.4 \mathrm{~g} / \mathrm{L} \mathrm{GR}\left(\mathrm{CO}_{3}{ }^{2-}\right)$ suspension buffered at $\mathrm{pH}$ 7.5 with deoxygenated $25 \mathrm{mM}$ MOPS buffer or $50 \mathrm{mM}$ carbonate buffer. Each headspace-free reactor was capped with a PTFE-lined septa and an aluminum crimp cap. The assembly of reactors was conducted in an anaerobic chamber. After preparation, the reactors were removed from the chamber and wrapped with aluminum foil to prevent potential photolysis reactions. Kinetic experiments were initiated with injection of the target DBP dissolved in methanol or MTBE. The initial concentrations of TCAN, DCAN, 1,1,1-TCP, and TCAh were approximately $100 \mu \mathrm{M}$, which is 10 to 100-fold higher than those typically found in distribution systems. Due to low detections limit for some of the reactants, intermediates, and final products in reactions with haloacetic acids and halonitromethanes, experiments were conducted at higher initial concentrations (500-700 $\mu \mathrm{M})$. Reactors were mixed about their longitudinal axes on a rotator at a speed of $50 \mathrm{rpm}$ at $22 \pm 3{ }^{\circ} \mathrm{C}$. Suspension samples were withdrawn at desired time intervals by injecting deoxygenated buffer to avoid the introduction of headspace. Initial and final $\mathrm{pH}$ values of the batch reactors were also monitored. At the end of the experiments, the mineral was collected as described above and analyzed using XRD. Control experiments were performed in a similar manner without $\mathrm{GR}\left(\mathrm{CO}_{3}{ }^{2-}\right)$ to verify compound hydrolysis, but hydrolysis rate constants were determined from experiments containing $\mathrm{GR}\left(\mathrm{CO}_{3}{ }^{2-}\right)$ due to drifting $\mathrm{pH}$ values when $\mathrm{GR}\left(\mathrm{CO}_{3}{ }^{2-}\right)$ was present. 
Section S5. Analytical Methods

With the exceptions of the haloacetic acids, NM, and MA, all species were detected and quantified using gas chromatography (GC) with electron capture detection (Trace GC, ThermoQuest) after a $0.5 \mathrm{~mL}$ suspension sample $(0.1 \mathrm{~mL}$ for halonitromethanes) was extracted with $1.0 \mathrm{~mL}$ MTBE. A $1 \mu \mathrm{L}$ sample of the MTBE extract was injected by an AS2000 liquid autosampler (ThermoQuest) onto a DB-1 column $(30 \mathrm{~m} \times 0.32 \mathrm{~mm}$ i.d. $\times 5 \mu \mathrm{m}$ film thickness, J\&W Scientific) via an on-column injection. The temperature of the electron capture detector was 290 or $300{ }^{\circ} \mathrm{C}$. Detailed oven temperature programs for individual compounds were similar to those described previously (3).

For the haloacetic acids, NM, and MA, suspension samples were filtered though a $0.2 \mu \mathrm{m}$ PTFE Gelman Acrodisk syringe tip filter to remove iron mineral particles and to stop the reaction. Capillary electrophoresis (CE) was used for analysis of the haloacetic acids (4). Aqueous $\mathrm{Fe}(\mathrm{II})$ in the sample was oxidized to form precipitates by exposure to air, and the precipitates were removed by passing the sample though a $0.2 \mu \mathrm{m}$ PTFE Gelman Acrodisk syringe tip filter. The filtered sample was then analyzed. NM was analyzed using headspace GC with flame ionization detection by a modified method of Pearson et al. (5). A $0.5 \mathrm{~mL}$ filtered sample was added to a $2.5 \mathrm{~mL}$ vial and capped with a PTFE-lined septa and aluminum crimp cap. After incubation at $50^{\circ} \mathrm{C}$ for 20 minutes, a $250 \mu \mathrm{L}$ sample of the headspace was injected (splitless, $150{ }^{\circ} \mathrm{C}$ ) onto a GS-GasPro Column (30 $\mathrm{m} \times 0.32 \mathrm{~mm}$ i.d., J\&W Scientific) by an HS2000 headspace autosampler (ThermoQuest). The oven temperature was initially held at 90 ${ }^{\circ} \mathrm{C}$ for 1 minute. This was followed by a temperature increase of $25^{\circ} \mathrm{C} /$ minute to $228{ }^{\circ} \mathrm{C}$. The temperature was held at $228{ }^{\circ} \mathrm{C}$ for 5 minutes. The temperature was then increased $10{ }^{\circ} \mathrm{C} /$ minute to $240^{\circ} \mathrm{C}$, where was held for 2 minutes. MA was detected using high performance liquid chromatography (Waters LC Module 1 Plus) after derivatization of the filtered samples via a modified method of Gui et al. (6). A $30 \mu \mathrm{L}$ aliquot of 2,4-dinitrofluorobenzene, $100 \mu \mathrm{L}$ of acetonitrile, and $50 \mu \mathrm{L}$ of $0.1 \mathrm{M}$ sodium hydroxide were added to $0.4 \mathrm{~mL}$ of the filtered sample. The mixture was then vortexed. Aqueous Fe(II) was oxidized during the methyl amine derivatization process prior to HPLC analysis. The derivatized samples were transferred to autosampler vials after the precipitates had settled. A $20 \mu \mathrm{L}$ sample was injected onto a Discovery ${ }^{\circledR}$ RP Amide C18 column (15 cm $\times 4.6 \mathrm{~mm}$ i.d. $\times 5 \mu \mathrm{m}$ film thickness, Supelco $)$ and detection was performed at a wavelength of $380 \mathrm{~nm}$. The mobile phase was $0.2 \%$ acetic acid $(\mathrm{pH} 4) / \mathrm{methanol}$ $(1 / 1 \mathrm{v} / \mathrm{v})$ at a flow rate of $0.8 \mathrm{~mL} / \mathrm{min}$. 


\section{Section S6. Kinetic Modeling}

The overall, hydrolysis, and reductive dehalogenation pseudo-first-order rate constants of DBPs in each system were calculated using Scientist for Windows (v. 2.01, Micromath Research). Rate constants were determined by fitting concentration versus time data for both the parent compound and daughter products to the following equations:

$$
\begin{aligned}
& \frac{d C_{i}}{d t}=-k_{o b s} C_{i}=-\left(k_{r, i}+k_{h, i}\right) C_{i} \\
& \frac{d C_{j}}{d t}=k_{r, i} C_{i}+k_{h, k} C_{k}-\left(k_{r, j}+k_{h, j}\right) C_{j}
\end{aligned}
$$

where $\mathrm{C}$ represents aqueous concentrations and $k_{r}$ and $k_{h}$ values are pseudo-first order reduction rate constants and hydrolysis rate constants, respectively. Rate constants are determined by a least squares fit of the numerically integrated equations to the data. Equation (1) shows the reaction of the parent compound $i$. Equation (2) shows the formation of compound $j$ via reduction from parent $i$ or hydrolysis of another parent compound $k$. Compound $j$ may also react via reduction or hydrolysis. When fitting the data for a given compound, the reaction rate constants for the loss of daughter products were fixed at values found in independent experiments using daughter products as starting material, unless reaction of the daughter products was so slow over the experimental time frames that they could be set to zero (i.e., TCM). (The exception is NM, for which the rate constant for NM was calculated from the experiment using CNM as the starting material. An independent experiment using NM as starting material was conducted at a high initial concentration $(700 \mu \mathrm{M})$ so that the rate constant was not applicable for subsequent fitting.) Using this method, only the hydrolysis and reduction rate constants for the parent compound are fitting parameters. The equations above only allows for sequential reduction steps reactions. Parallel reactions (for example, both hydrogenolysis and reductive $\alpha$-elimination) were not necessary for the species or time scales studied (i.e., if a parallel reaction is included, the resulting fitted value is near zero). 


\section{Section S7. Determination of $\mathrm{E}_{1}{ }^{\mathrm{H}}$ values for TBAA and DBAA}

All calculations were performed with the Gaussian 03 electronic structure program suite(7). $\mathrm{E}_{1}{ }^{\mathrm{H}}$ values for the chlorinated species were determined previously by calculating gas phase energies using the G3MP2 method (8) and solvation energies using the Minnesota General Solvation Model (9) (values required updating; see below). For brominated species, however, the G3MP2 method/basis set combinations do not work. Thus, for brominated species the calculation steps within the G3MP2 method must be done individually with an appropriate basis set for bromine. In each of the following steps, user-specified basis sets were used via the general basis set keyword. For $\mathrm{H}$ and C, the basis set is then input as 6-31g* (10) and that for Br is cc-pVDZ (11-13), and 6D and 7F Cartesian functions are specified. The exception is the last step, in which the GTMP2large (8) basis set is used for $\mathrm{H}$ and $\mathrm{C}$ and the aug-cc-pVTZ (11-13) is used for Br, and 5D and 7F Cartesian functions are specified. The calculations are as follows: 1 . A hartree fock (HF) geometry optimization; 2. A frequency calculation at the HF level; 3. An energy calculation at the MP2(full) level; 4. An energy calculation via a quadratic CI calculation including single and double substitutions with a triples contribution to the energy added (QCISD(T)); and 5. An energy calculation at the MP2 level with the larger basis sets.

The gas phase free energy is then calculated via the following formula (8):

$$
\mathrm{E}=\mathrm{QCISD}(\mathrm{T})+(\text { MP2large-MP2) }+\mathrm{E}(\mathrm{HLC})+\mathrm{E}(\mathrm{TC})
$$

Where the first term is the energy calculated from the QCISD(T) step, the second term is the difference in the energies computed from the two MP2 calculations, the third term is a "higher level correction" based on the number of electrons in the atom or molecule, and the last term is a thermal correction to the free energy. In testing this formula on chlorinated compounds in which the calculations were done individually rather than using the G3MP2 method, it was found that two corrections had to be made to reproduce the G3MP2 results. First, the free energy correction obtained from the frequency calculation had to be multiplied by a factor of 0.9186 , not the 0.8929 given in ref. (8). Also, the $\triangle \mathrm{MP} 2$ term had to be divided by the scaling factor of 0.8929 . Gas phase energies were corrected from $\mathrm{P}=1 \mathrm{~atm}$ to a concentration of $1 \mathrm{~mol} / \mathrm{L}$. The free energies of solvation were then added to each species, and the free energy of reaction was determined by subtracting the solvated free energies of the products from those of the reactants. The free energy of reaction was then referenced to the normal hydrogen electrode (NHE) by subtracting $4.28 \mathrm{eV}$ (14). (Note that this is different than the value used for the chlorinated compounds originally calculated in ref. (3). The values for chlorinated compounds were updated to account for the error in the NHE correction pointed out in ref. (14)). An additional correction was made to reference the energy values to a bromide concentration of $1 \mathrm{mM}$. The $\mathrm{E}_{1}{ }^{\mathrm{H}}$ values were then determined from the free energy of reaction $(\Delta G=-n F E)$. 

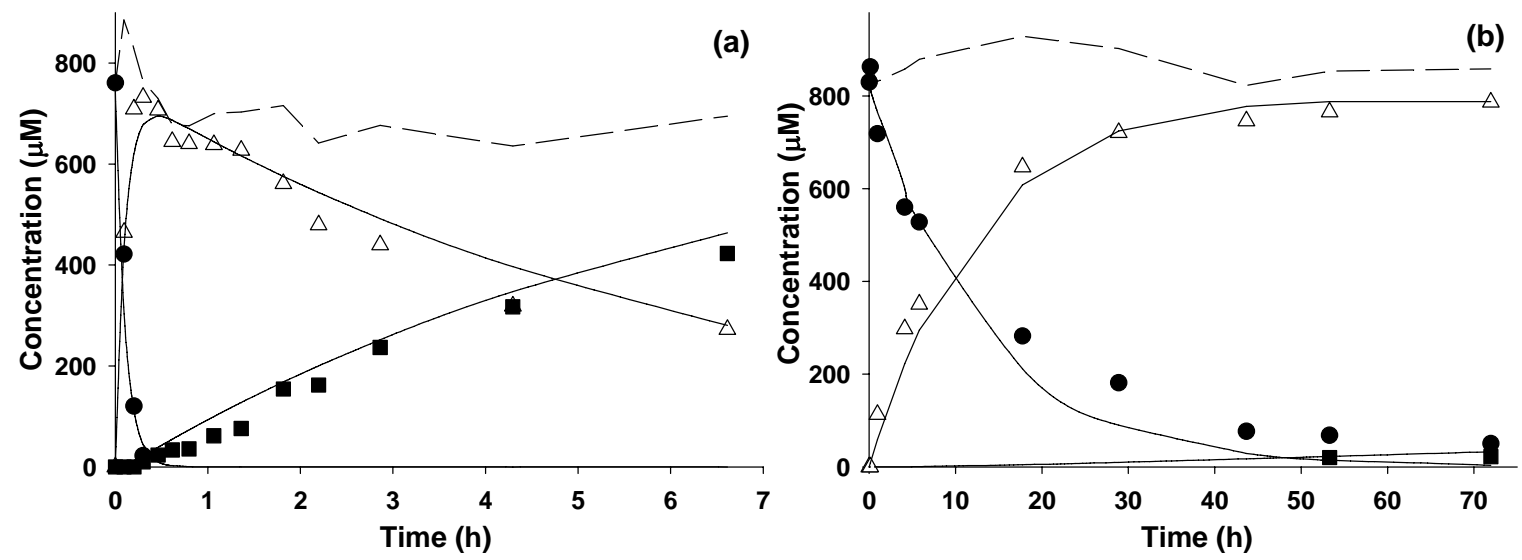

Figure S1. Degradation of (a) TBAA and (b) TCAA by GR( $\left(\mathrm{CO}_{3}{ }^{2-}\right)$ in the presence of 25 mM MOPS buffer (pH 7.5 and solid concentration 2.4 g/L). Trihaloacetic acid, $\mathbf{O}$; dihaloacetic acid, $\triangle$; monohaloacetic acid, $\boldsymbol{\square}$. The dashed line represents the observed carbon mass balance and the solid lines are model fits.

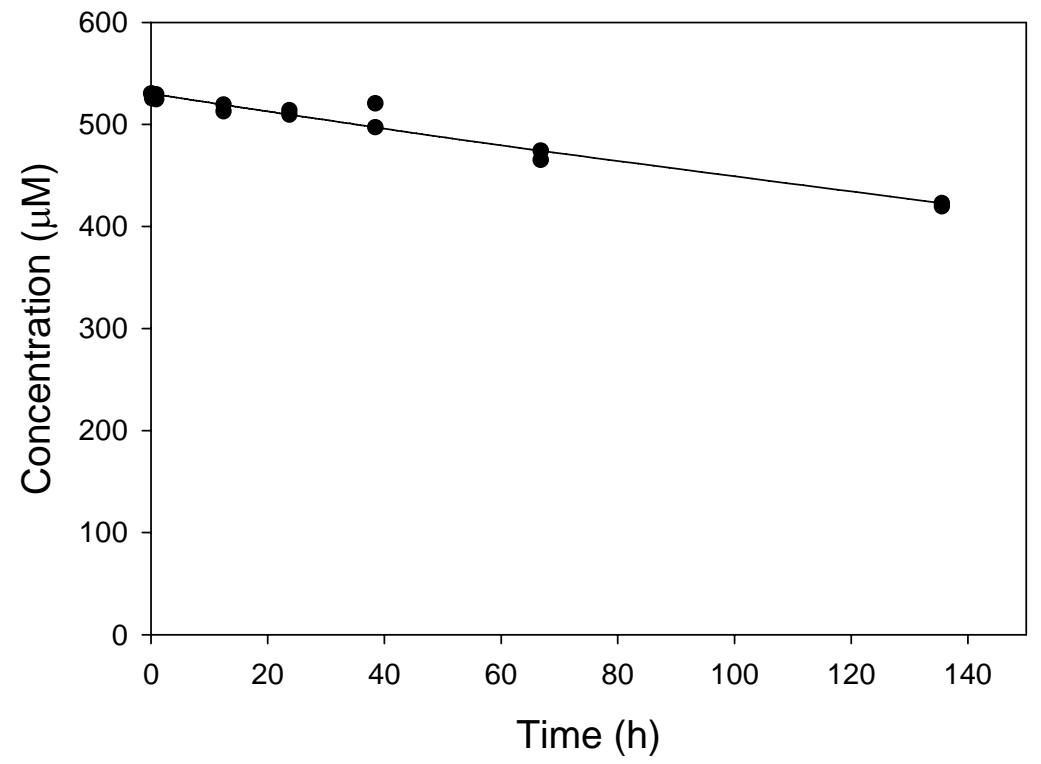

Figure S2. Degradation of BAA by GR( $\left(\mathrm{CO}_{3}{ }^{2-}\right) /$ magnetite in the presence of $25 \mathrm{mM}$ MOPS buffer at $\mathrm{pH} 7.5$ 

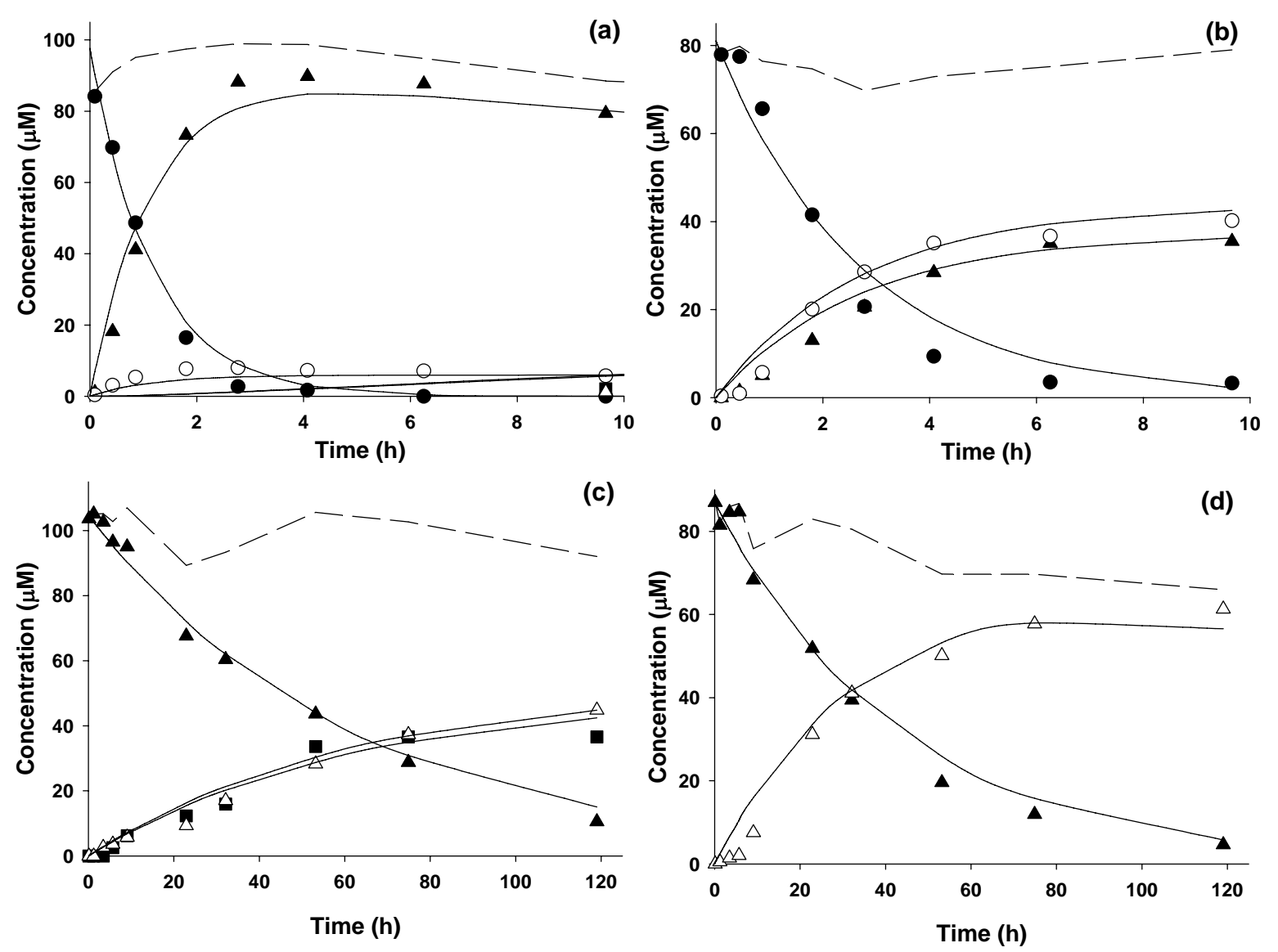

Figure S3. Degradation of TCAN ( $\bullet$, a \& b) by GR( $\left(\mathrm{CO}_{3}{ }^{2-}\right)$ and DCAN ( $\boldsymbol{\Delta}$, c \& d) by $\mathrm{GR}\left(\mathrm{CO}_{3}{ }^{2}\right) /$ magnetite in the presence of $25 \mathrm{mM}$ MOPS buffer (a \& c) and $50 \mathrm{mM}$ carbonate buffer (b \& d). Major products are TCAM $(O)$, CAN $(\mathbf{\square})$, and DCAM $(\triangle)$ ). The dashed line represents the observed carbon mass balance and the solid lines are model fits. The initial $\mathrm{pH}$ was 7.5 and the solid loading was $2.4 \mathrm{~g} / \mathrm{L}$. 

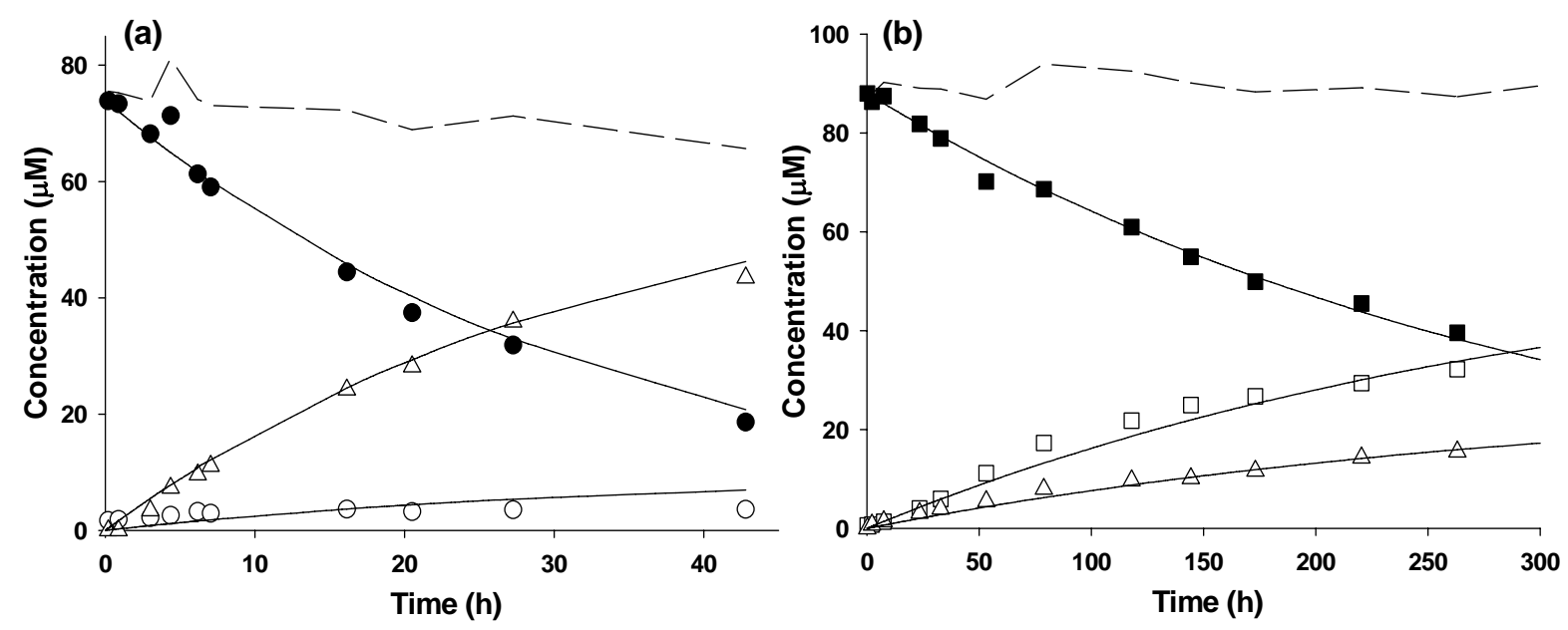

Figure S4. Degradation of TCP $\left(\boldsymbol{O}\right.$, a) and TCAh $\left(\boldsymbol{\square}\right.$, b) by $\operatorname{GR}\left(\mathrm{CO}_{3}{ }^{2-}\right) /$ magnetite in the presence of $25 \mathrm{mM}$ MOPS buffer. Major products of TCP degradation are DCP $(\bigcirc$, a) and $\operatorname{TCM}(\triangle, a)$ and those of TCAh degradation are DCAh $(\square, b)$ and $\operatorname{TCM}(\triangle, b)$. The dashed line represents the observed carbon mass balance and the solid lines are model fits. All experiments were conducted at $\mathrm{pH} 7.5$ with a solid loading of $2.4 \mathrm{~g} / \mathrm{L}$. 

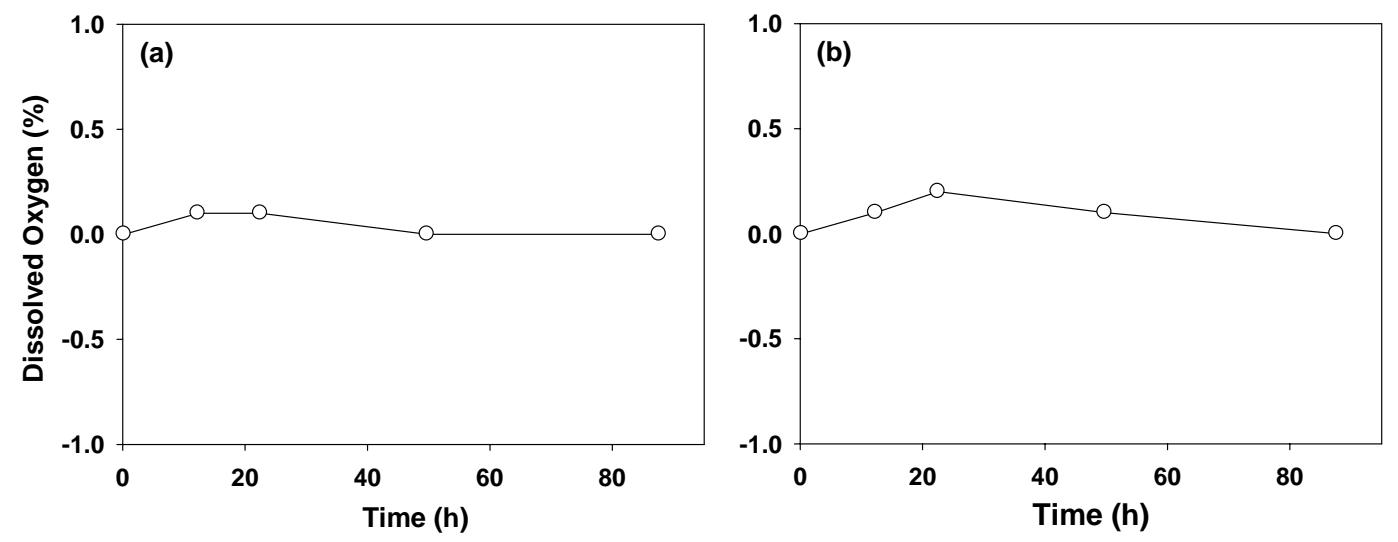

Figure S5. Dissolved oxygen $(\mathrm{O})$ in control experiments without $\mathrm{GR}\left(\mathrm{CO}_{3}{ }^{2-}\right)$ and DBP: (a) $25 \mathrm{mM}$ deoxygenated MOPS buffer and (b) $50 \mathrm{mM}$ deoxygenated carbonate buffer. The $\mathrm{pH}$ of each buffer is 7.5. Dissolved oxygen was monitored using a MI-730 micro-oxygen electrode.
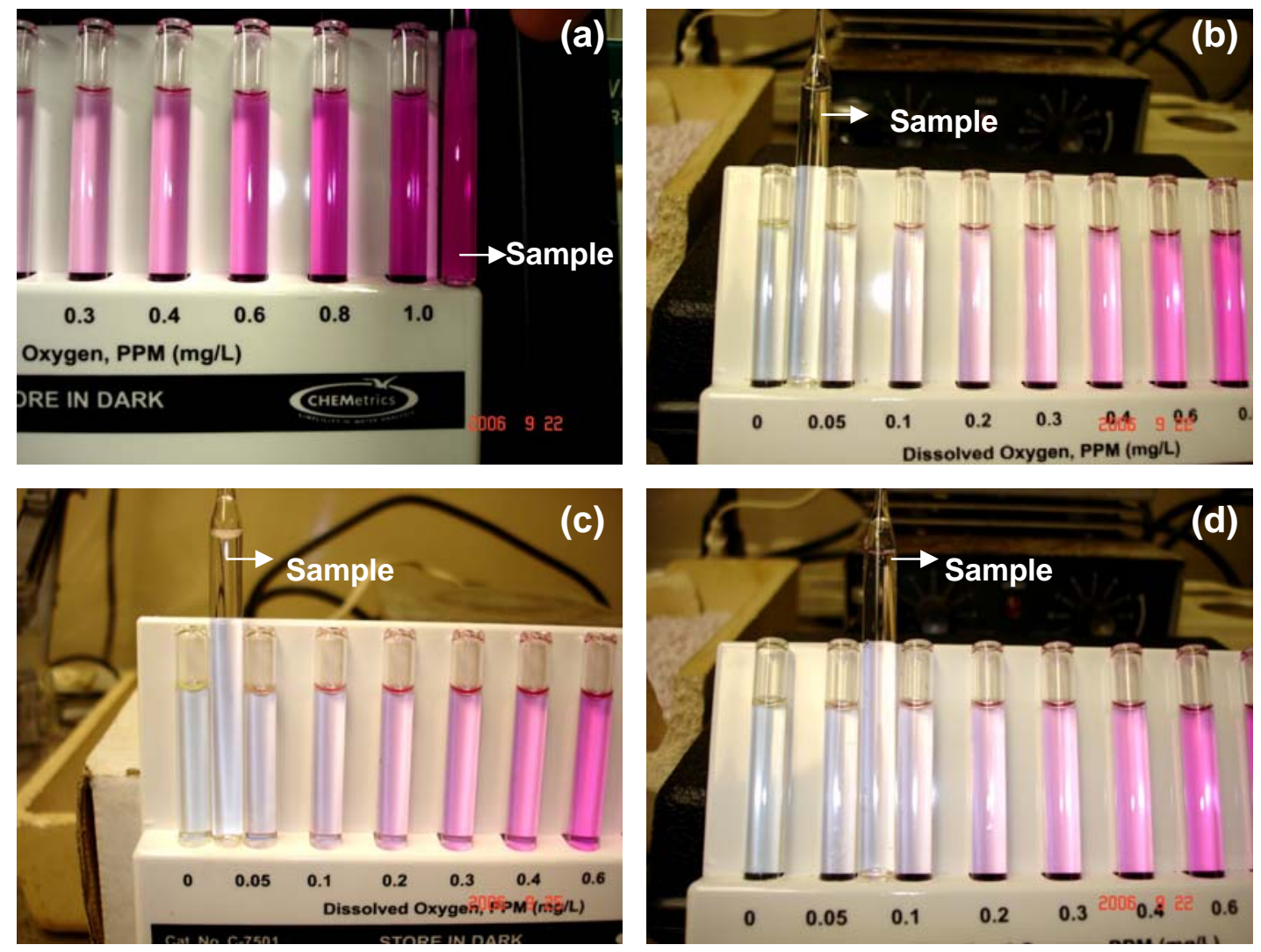

Figure S6. Dissolved oxygen concentration of (a) Milli-Q water before deoxygenation (> 1 ppm), (b) deoxygenated Milli-Q water (0-0.05 ppm) which is used for calibration of the MI-730 micro-oxygen electrode, (c) $25 \mathrm{mM}$ deoxygenated MOPS buffer after a 90h-control experiment (Figure S5a, 0-0.05 ppm), and (d) $50 \mathrm{mM}$ deoxygenated carbonate buffer after a 90h-control experiment (Figure S5b, 0.05-0.1 ppm). Dissolved oxygen was measured using DO CHEMets ${ }^{\circledR}$. 


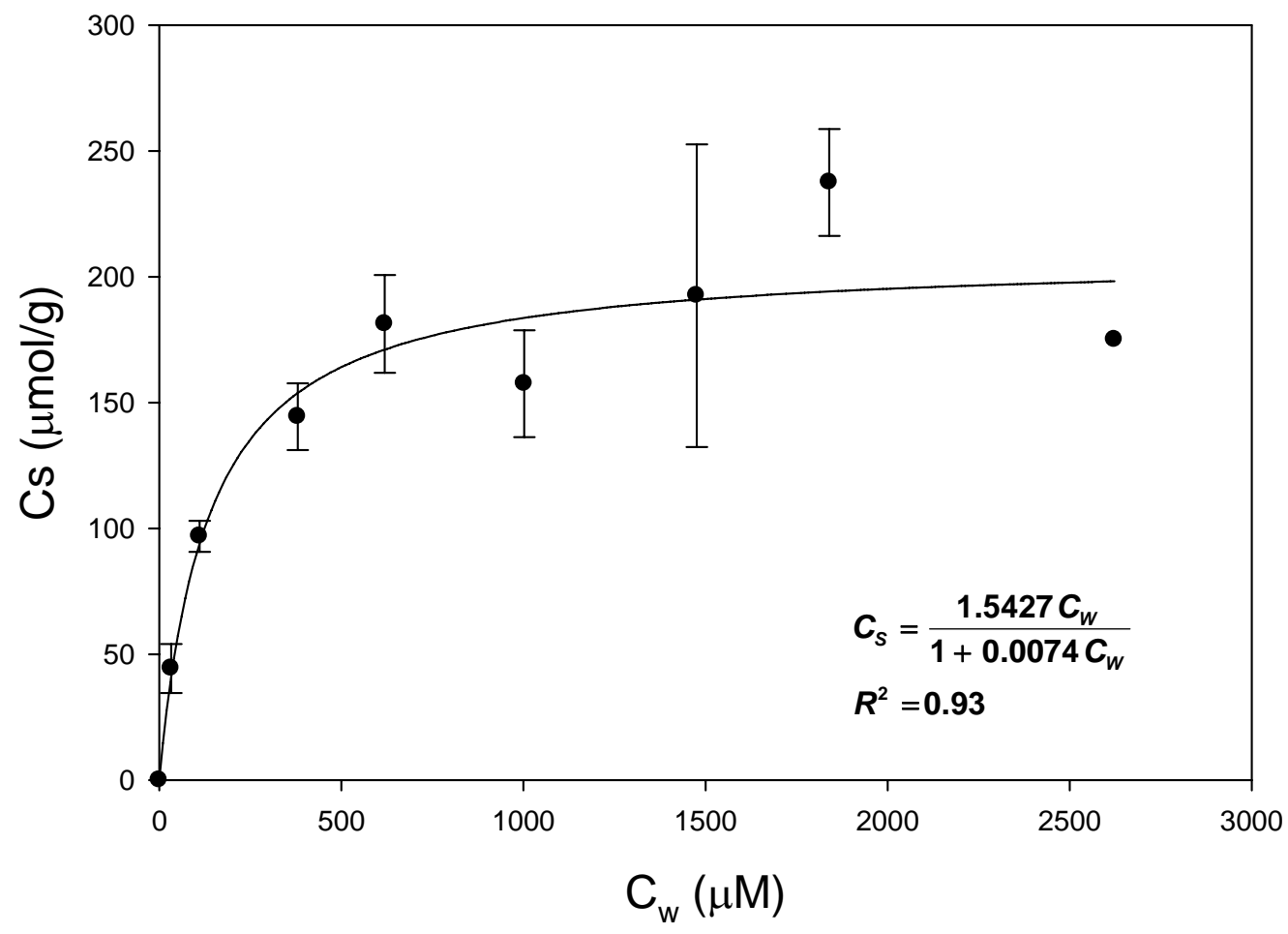

Figure S7. Sorption isotherm of Fe(II) onto magnetite whose surface area is $87 \mathrm{~m}^{2} / \mathrm{g}$. This magnetite was used in the study conducted by Chun et al (3). 

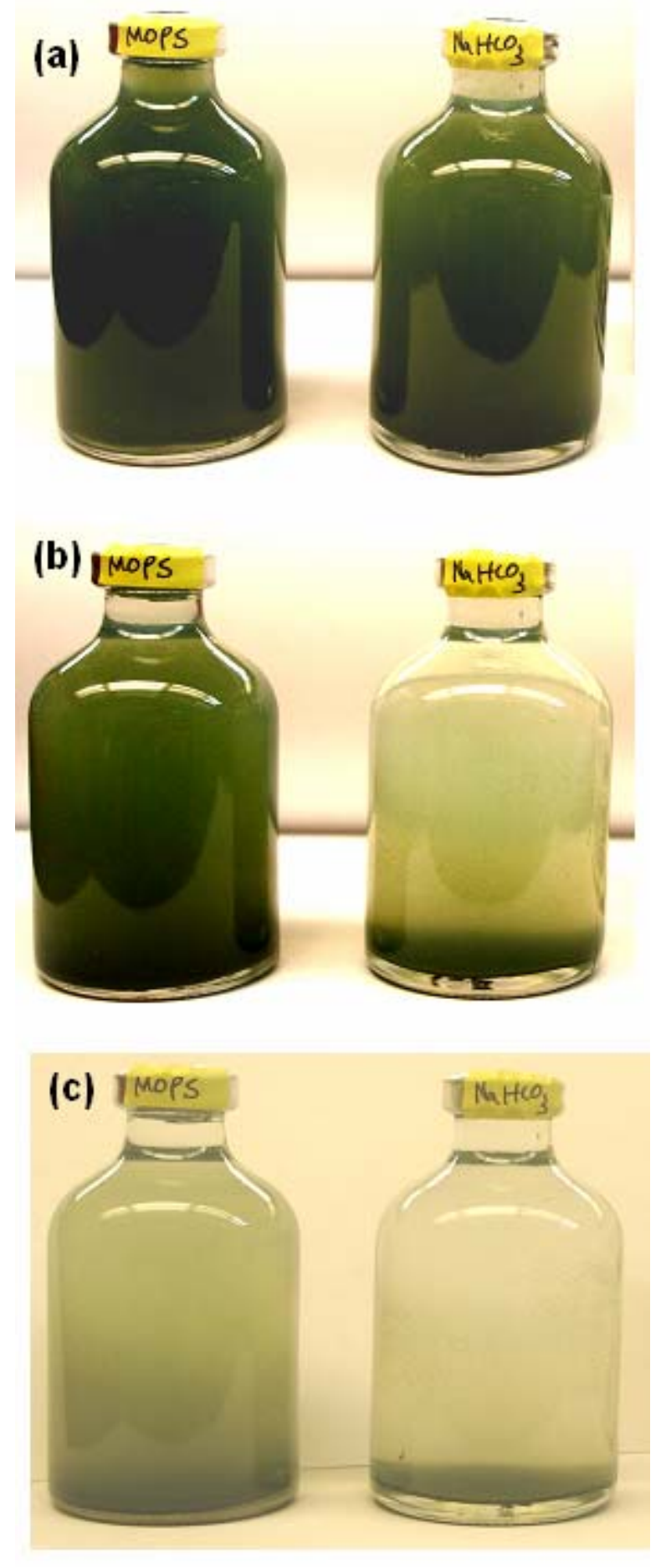

Figure S8. Settling of $\mathrm{GR}\left(\mathrm{CO}_{3}{ }^{2-}\right)(1.5 \mathrm{~g} / \mathrm{L})$ in $25 \mathrm{mM}$ MOPS buffer and $50 \mathrm{mM}$ carbonate buffer at pH 7.5 (a) 30 sec. (b) 15 min. and (c) 1 hour. 

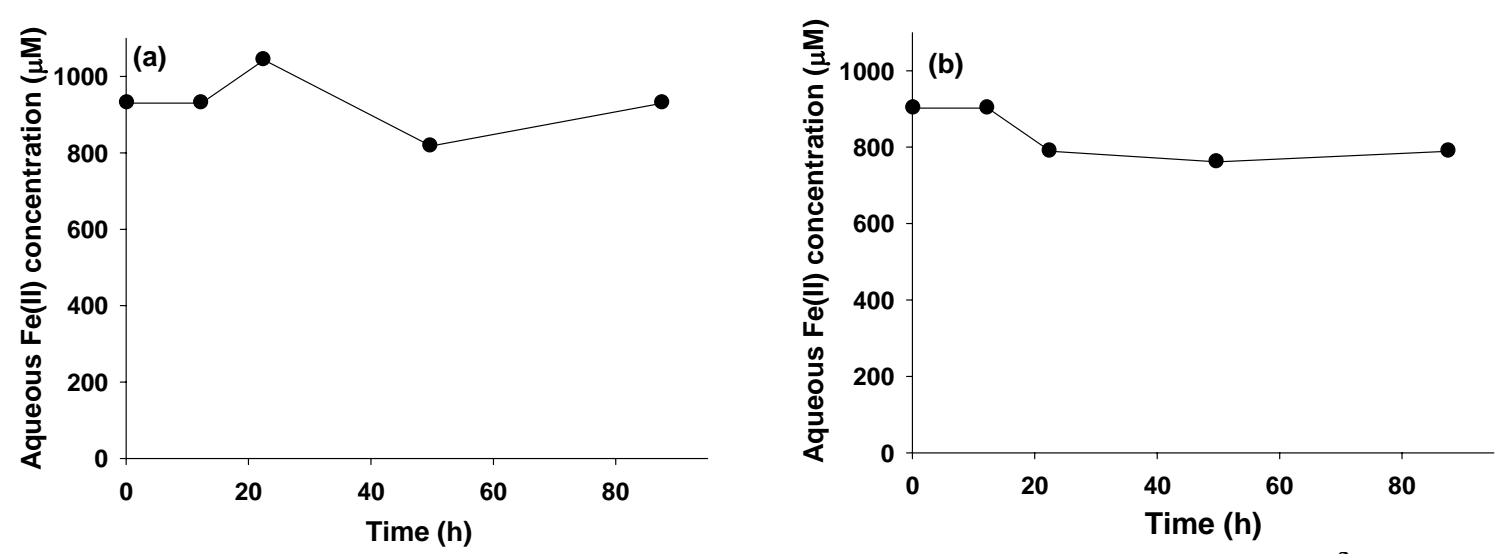

Figure S9. Aqueous $\mathrm{Fe}(\mathrm{II})$ concentration in control experiments without $\mathrm{GR}\left(\mathrm{CO}_{3}{ }^{2-}\right)$ and $\mathrm{DBP}$ : (a) $25 \mathrm{mM}$ deoxygenated MOPS buffer and (b) $50 \mathrm{mM}$ deoxygenated carbonate buffer. The $\mathrm{pH}$ of each buffer is 7.5. Aqueous Fe(II) was measured using the Ferrozine method. 


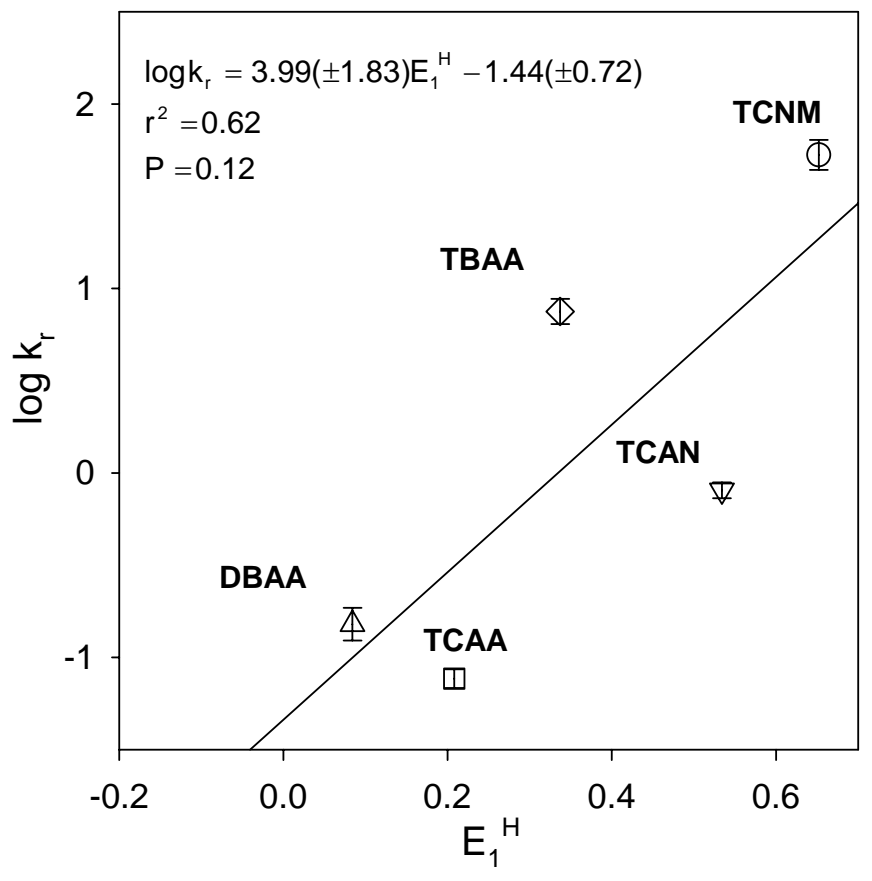

Figure S10. Correlation of dehalogenation rate constant $\left(k_{r}\right)$ with one electron reduction potential $\left(\mathrm{E}_{1}{ }^{\mathrm{H}}\right)$. Error bars represent $95 \%$ confidence limits. The $\mathrm{k}_{\mathrm{r}}$ values were from experiments performed in $25 \mathrm{mM}$ MOPS buffer at $\mathrm{pH} 7.5$ and a $\mathrm{GR}\left(\mathrm{CO}_{3}{ }^{2-}\right)$ loading of $2.4 \mathrm{~g} / \mathrm{L}$. 
References

1. Williams, A.G. and Scherer, M.M. Kinetics of $\mathrm{Cr}(\mathrm{VI})$ reduction by carbonate green rust. Environ. Sci. Technol. 2001, 35(17), 3488-3494.

2. Stookey, L. L. Ferrozine- a new spectrophotometric reagent for iron. Anal. Chem. 1970, 42, 779-781.

3. Chun, C.L., Hozalski, R.M., and Arnold, W.A. Degradation of drinking water disinfection byproducts by synthetic goethite and magnetite. Environ. Sci. Technol. 2005, 39(21), 85258532.

4. Hozalski, R.M., Zhang, L., and Arnold, W.A. Reduction of haloacetic acids by $\mathrm{Fe}^{0}$ : Implications for treatment and fate. Environ. Sci. Technol. 2001, 35(11), 2258-2263.

5. Pearson, C.R., Hozalski, R.M., and Arnold, W.A. Degradation of chloropicrin in the presence of zero-valent iron. Environ. Toxicol. Chem. 2005, 24(12), 3037-3042.

6. Gui, L., Gillham, R.W., and Odziemkowski, M.S. Reduction of N-nitrosodimethylamine with granular iron and nickel-enhanced iron. 1. Pathways and kinetics. Environ. Sci. Technol. 2000, 34(16), 3489-3494.

7. Frisch, M.J., Trucks, G.W., Schlegel, H.B., Scuseria, G.E., Robb, M.A., Cheeseman, J.R., Montgomery, J., J. A., Vreven, T., Kudin, K.N., Burant, J.C., Millam, J.M., Iyengar, S.S., Tomasi, J., Barone, V., Mennucci, B., Cossi, M., Scalmani, G., Rega, N., Petersson, G.A., Nakatsuji, H., Hada, M., Ehara, M., Toyota, K., Fukuda, R., Hasegawa, J., Ishida, M., Nakajima, T., Honda, Y., Kitao, O., Nakai, H., Klene, M., Li, X., Knox, J.E., Hratchian, H.P., Cross, J.B., Bakken, V., Adamo, C., Jaramillo, J., Gomperts, R., Stratmann, R.E., Yazyev, O., Austin, A.J., Cammi, R., Pomelli, C., Ochterski, J.W., Ayala, P.Y., Morokuma, K., Voth, G.A., Salvador, P., Dannenberg, J.J., Zakrzewski, V.G., Dapprich, S., Daniels, A.D., Strain, M.C., Farkas, O., Malick, D.K., Rabuck, A.D., Raghavachari, K., Foresman, J.B., Ortiz, J.V., Cui, Q., Baboul, A.G., Clifford, S., Cioslowski, J., Stefanov, B.B., Liu, G., Liashenko, A., Piskorz, P., Komaromi, I., Martin, R.L., Fox, D.J., Keith, T., Al-Laham, M.A., Peng, C.Y., Nanayakkara, A., Challacombe, M., Gill, P.M.W., Johnson, B., Chen, W., Wong, M.W., Gonzalez, C., and Pople, J.A., Gaussian 03 (Revision D.01). 2004, Wallingford, CT: Gaussian, Inc.

8. Curtiss, L.A., Redfern, P.C., Raghavachari, K., Rassolov, V., and Pople, J.A. Gaussian-3 theory using reduced Møller-Plesset order. J. Chem. Phys. 1999, 110(10), 4703-4709.

9. Chamberlin, A.C., Kelly, C.P., Thompson, J.D., Xidos, J.D., Li, J., Hawkins, G.D., Winget, P.D., Zhu, T., Rinaldi, D., Liotard, D.A., Cramer, C.J., Truhlar, D.G., and Frisch, M.J. MNGSM, version 6.0. University of Minnesota, Minneapolis, MN 55455-0431 2006.

10. Binkley, J.S., Pople, J.A., and Hehre, W.J. Extended basis set studies of hydrocarbon molecular orbital energies. Chem. Phys. Lett. 1975, 36(1), 1-5.

11. Dunning, T.H. Gaussian Basis Sets for Use in Correlated Molecular Calculations. 1. The Atoms Boron through Neon and Hydrogen. J. Chem. Phys. 1989, 90, 1007-1023.

12. Kendall, R.A., Dunning, T.H., and Harrison, R.J. aug-cc-pVDZ for first row. J. Chem. Phys. 1992, 96, 6796-6806.

13. Woon, D.E. and Dunning, T.H. Gaussian Basis Sets for Use in Correlated Molecular Calculations. III. The Atoms Aluminum through Argon. J. Chem. Phys. 1993, 98(2), 13581371.

14. Kelly, C.P., Cramer, C.J., and Truhlar, D.G. Aqueous Solvation Free Energies of Ions and Ion-Water Clusters Based on an Accurate Value for the Absolute Aqueous Solvation Free Energy of the Proton. J. Phys. Chem. B 2006, 110(32), 16066-16081. 